\title{
Electrochemical Deposition and Dissolution of Aluminum in NaAICl4 Melts Influence of $\mathrm{MnCl} 2$ and Sulfide Addition
}

\section{Li, Qingfeng; Hjuler, H.A.; Berg, Rolf W.; Bjerrum, Niels}

Published in:

Journal of The Electrochemical Society

Link to article, DOI:

$10.1149 / 1.2087074$

Publication date:

1990

Document Version

Publisher's PDF, also known as Version of record

Link back to DTU Orbit

Citation (APA):

Li, Q., Hjuler, H. A., Berg, R. W., \& Bjerrum, N. (1990). Electrochemical Deposition and Dissolution of Aluminum in $\mathrm{NaAlCl} 4$ Melts: Influence of $\mathrm{MnCl} 2$ and Sulfide Addition. Journal of The Electrochemical Society, 137(9), 2794-2798. https://doi.org/10.1149/1.2087074

\section{General rights}

Copyright and moral rights for the publications made accessible in the public portal are retained by the authors and/or other copyright owners and it is a condition of accessing publications that users recognise and abide by the legal requirements associated with these rights.

- Users may download and print one copy of any publication from the public portal for the purpose of private study or research.

- You may not further distribute the material or use it for any profit-making activity or commercial gain

- You may freely distribute the URL identifying the publication in the public portal 
edge-plane defects and crystallite sizes are found to alter (with time at constant current) by both Raman and STM. The surface oxidation was not monitored by STM, since our interest is in changes occurring on a much larger scale $(1 \mu \mathrm{m})$, comparable to the laser-spot size. However, close inspection of the Raman spectrum in Fig. $2 \mathrm{~d}$ shows the appearance of a small band at approximately $1750 \mathrm{~cm}^{-1}$, indicating that sufficient oxidation has taken place on the surface and within the region of penetration depth of the laser beam to be detected spectroscopically.

\section{Conclusions}

Pyrolytic graphite electrodes subjected to anodic currents in an electrochemical bath change structurally in both the near-surface and surface layers. Currents of $2 \mathrm{~mA} / \mathrm{cm}^{2}$ for $2 \mathrm{~h}$ produces little change in the surface, but after $24 \mathrm{~h}$ changes in crystallite size and edge-plane density is seen. In contrast, $10 \mathrm{~mA} / \mathrm{cm}^{2}$ current for $2 \mathrm{~h}$ produces noticeable changes and after $24 \mathrm{~h}$ can cause severe damage. The changes in island formation, edge-plane density, defects, and lattice disorder may be detected by Raman spectroscopy and STM. General agreement between the results of both analytical methods indicate that complementary information may be gained from similar studies involving graphitic structures.

\section{Acknowledgments}

The author wishes to express thanks to C. Reidsema and J. Varsik for supplying the electrodes.

Manuscript submitted Sept. 11, 1989; revised manuscript received March 27, 1990.

IBM Technology Division assisted in meeting the publication costs of this article.

\section{REFERENCES}

1. R. O. Dillon, J. A. Wollam, and V. Katkanant, Phys. Rev. B, 29, 3482 (1984).

2. R. J. Bowling, R. T. Packard, and R. L. McCreery, J. Am. Chem. Soc., 111, 1217 (1989).

3. A. Marchand, P. Lespade, and M. Couzi in "Extended Abstracts of the 15th Biennial Conference on Carbon," F. L. Vogel and W. C. Foseman, Editors, p. 282, American Carbon Society, University of Pennsylvania (1981).

4. G. Binnig and H. Rohrer, Helv. Phys. Acta, 55, 726 (1982).

5. G. Binnig and H. Rohrer, Surf. Sci., 126, 236 (1983).

6. E. Ganz, K. Sattler, and J. Clarke, J. Vac. Sci. Technol., A6, 419 (1988).

7. H. Fuchs, Physica Scripta, 38, 264 (1988).

8. C. A. Lang, J. K. H. Horber, T. W. Hansch, W. M. Heckland, and H. Mohwald, J. Vac. Sci. Technol., A6, 368 (1988).

9. A. Bryant, D. P. E. Smith, and C. F. Quate, Appl. Phys. Lett., 48, 832 (1988).

10. V. Elings and F. Wudl, J. Vac. Sci. Technol., A6, 412 (1988).

11. J. W. Lyding, J. S. Hubacek, G. Gammie, S. Skala, R. Brockenbrough, J. R. Shapley, and M. P. Keyes, ibid., A6, 363 (1989).

12. A. A. Gewirth and A. J. Bard, J. Phys. Chem., 92, 5563 (1988).

13. L. M. Siperko, Paper presented at Fifth International Conference on Scanning Tunneling Microscopy/ Spectroscopy, Baltimore, MD, July 23-27, 1990.

14. "Principles of Electronic Packaging," Seraphim, Lasky, and $\mathrm{Li}$, Editors, Chap. 16, McGraw Hill, Inc., New York (1989).

15. F. Tuinstra and J. L. Koenig, J. Chem. Phys., 53, 1126 (1978).

\title{
Electrochemical Deposition and Dissolution of Aluminum in $\mathrm{NaAlCl}_{4}$ Melts Influence of $\mathrm{MnCl}_{2}$ and Sulfide Addition
}

\author{
Li Qingfeng, H. A. Hjuler, ${ }^{\star}$ R. W. Berg, and N. J. Bjerrum \\ Molten Salts Group, Chemistry Department A, The Technical University of Denmark, DK-2800 Lyngby, Denmark
}

\section{ABSTRACT}

Effects of the additives $\mathrm{MnCl}_{2}$, sulfide, and their combined influence on aluminum deposition and dissolution in $\mathrm{NaAlCl}_{4}$ saturated with $\mathrm{NaCl}$ have been studied by polarization measurements, galvanostatic deposition, and current reversal chronopotentiometry (CRC). The solubility of $\mathrm{MnCl}_{2}$ was found to be $0.086 \pm 0.006 \mathrm{~m} / \mathrm{o}$ in the melt at $175^{\circ} \mathrm{C}$. Aluminum-manganese alloys can be deposited in $\mathrm{NaAlCl}_{4}$ saturated with both $\mathrm{NaCl}$ and $\mathrm{MnCl}_{2}$, resulting in a slight increase in cathodic overpotentials. The codeposition of the binary alloys at current densities below $4 \mathrm{~mA} / \mathrm{cm}^{2}$ gave rise to formation of deposits so compact that their specific average volumes are of the theoretical value. The content of manganese in the alloy deposits was found to be between 8-11 a/o. It was found that the manganese content in the deposits did not depend on the current efficiency. The presence of sulfide in $\mathrm{NaAlCl}_{4}$ results in the formation of more spongy deposits at low current densities, and thus destroys the beneficial effects of $\mathrm{MnCl}_{2}$ when both additives are present, but prevents formation of dendritic deposits at high current densities. Coulombic ratios of dissolution to deposition were found by CRC measurements to be affected by the nature of the substrate.

Aluminum electrodeposition from $\mathrm{AlCl}_{3}$-based molten salts has been the subject of many investigators (1). In most cases the electrolysis has been performed in the following ranges: temperature $150^{\circ}-180^{\circ} \mathrm{C}$, current density $20-50 \mathrm{~mA} / \mathrm{cm}^{2}$, and concentration of $\mathrm{AlCl}_{3} 56-64$ mole percent $(\mathrm{m} / \mathrm{o})$. These melts have a high vapor pressure which may lead to a high evaporation of $\mathrm{AlCl}_{3}$. At preferable concentrations, close to $50 \mathrm{~m} / \mathrm{o} \mathrm{AlCl}$, with $\mathrm{AlCl}_{3}$ bound as the stable complex $\mathrm{AlCl}_{4}{ }^{-}$, smooth aluminum layers could be deposited only in the current density range $2-10 \mathrm{~mA} / \mathrm{cm}^{2}$. At higher current densities aluminum was deposited in the form of dendrites or very porous powders. Surface-active components such as tetraalkylammonium halides (2-5) and urea (5) have been suggested as electroplating aiding

* Electrochemical Society Active Member. agents. In the case of rechargeable batteries, the oxidationreduction conditions are more demanding, and slow decomposition can make organic additives unfavorable (6). The effects of many inorganic additives have also been investigated. Among them, $\mathrm{BaCl}_{2}(7)$ was found to have little effect, whereas $\mathrm{PbCl}_{2}(3,8), \mathrm{SnCl}_{2}(3,9,10), \mathrm{MnCl}_{2}(3,11-13)$, $\mathrm{NaBr}$, and $\mathrm{NaI}(3,14)$ were found to have some beneficial effects on aluminum deposition. Iron chloride as an impurity in the chemicals, however, might make deposits even worse (15).

In our preliminary investigations (16), the effects of some inorganic additives on the morphology of aluminum were widely investigated. There were: $\mathrm{GaCl}_{3}, \mathrm{InCl}_{3}, \mathrm{BiCl}_{3}$, $\mathrm{HgCl}_{2}, \mathrm{CdCl}_{2}, \mathrm{PbCl}_{2}, \mathrm{SnCl}_{2}$, and $\mathrm{MnCl}_{2}$. Sulfide is of interest because it is present in the electrolyte of a newly developed battery having transition metal sulfides (e.g., 
$\mathrm{Ni}_{2} \mathrm{~S}_{3}$ ) as cathode (17). $\mathrm{MnCl}_{2}$, among others, was found to be the most favorable additive. In the present paper, the influences of manganese chloride, sulfide, and their combination on aluminum deposition and dissolution are presented.

\section{Experimenta}

Chemicals.-The preparation of distilled aluminum chloride and dried $\mathrm{NaCl}$ has been described previously (18). $\mathrm{NaAlCl}_{4}$ salts prepared from an equimolar mixture of distilled $\mathrm{AlCl}_{3}$ and dried $\mathrm{NaCl}$ of analytic grade were further purified by zone refining (1). Manganese dichloride was prepared from analytical reagent $\mathrm{MnCl}_{2} \cdot 4 \mathrm{H}_{2} \mathrm{O}$ by successively passing $\mathrm{HCl}$ gas over the solid salt at its dehydration temperatures $\left(106^{\circ}\right.$ and $\left.198^{\circ} \mathrm{C}\right)$ and then through the melt at $650^{\circ} \mathrm{C}$. Finally, the melt was flushed with pure $\mathrm{N}_{2}$ and filtered. Sulfide in form of $\mathrm{NaAlSCl}_{2}$ was prepared stoichiometrically at $250^{\circ} \mathrm{C}$ according to the following equilibrium [19]

$$
2 \mathrm{NaCl}+\mathrm{NaAlCl}_{4}+3 \mathrm{~S}+2 \mathrm{Al} \rightarrow 3 \mathrm{NaAlSCl}_{2}
$$

with extra $\mathrm{NaAlCl}_{4}$ as solvent.

Electrode and cell assembly.-A glassy carbon electrode of $3 \mathrm{~mm}$ diam was used as the working electrode in the deposition experiments. Aluminum electrodes of $99.999 \%$ purity were used both as counter and reference electrodes. The cell assembly and the preparation of the electrodes were the same as described in the previous paper (1).

Instruments and measurements.-The solubility of manganese dichloride in $\mathrm{NaAlCl}_{4}$ saturated with $\mathrm{NaCl}$ was measured by atomic absorption analysis in combination with visual observation. The melts with excessive $\mathrm{MnCl}_{2}$ were charged, evacuated, and sealed in Pyrex ampuls. At the test temperatures, the melts were maintained for $100 \mathrm{~h}$ and then filtered through a built-in ceramic filter by turning the cell upside down. The filtered solidified melts were then analyzed.

Cathodic polarization measurements were carried out by recording a steady-state potential with a X-t recorder after setting a constant current step by step.

The alloy samples were deposited onto a glassy carbon electrode. After deposition, the electrode was carefully removed from the melt, washed initially with dimethyl sulf oxide, then with thionyl chloride ( $>99 \%$ ), and finally with distilled water. The composition of aluminum-manganese alloys was analyzed by EDX using a Philips SEM 505 equipped with an EDAX analyzer.

Current reversal chronopotentiometry (CRC) was performed by using a Keithley 224 Programmable Current Source. A Keithley 199 System DMM/Scanner was used to monitor the potential. All measurements were controlled by an IBM-compatible computer with a battery test program developed in this laboratory.

All handlings of chemicals were performed in a dry-airfilled glove box (dew point $<-50^{\circ} \mathrm{C}$ ). Most of the experiments, deposition, current reversal chronopotentiometry, and polarization measurements were performed in a seethrough oven (1). The deposits were observed by using a Zeiss Jena Technival 2 Stereo Microscope equipped with an Olympus OM-2 SLR camera and a Schott KL 1500 cold light source. The morphology of the deposits was examined by microphotography and the specific volumes of the deposits were measured as averages from the pictures.

In all melts containing $\mathrm{MnCl}_{2}$, saturated concentration of $\mathrm{MnCl}_{2}$ was used except for the melts containing sulfide, in the form of $1.5 \mathrm{~m} / \mathrm{o} \mathrm{NaAlSCl}{ }_{2}$. In the latter case the concentration of $\mathrm{MnCl}_{2}$ when present was $\sim 0.1 \mathrm{~m} / \mathrm{o}$.

\section{Results and Discussion}

Solubility of manganese dichloride.-Figure 1 shows the resulting solubility of $\mathrm{MnCl}_{2}$ in the $\mathrm{NaCl}$-saturated $\mathrm{NaAlCl}_{4}$ melt. The solubilities increase with temperature and the following relationship is obtained by regression analysis

$$
\mathrm{S}(\mathrm{m} / \mathrm{o})=\frac{1}{19.44-0.04436 t}
$$

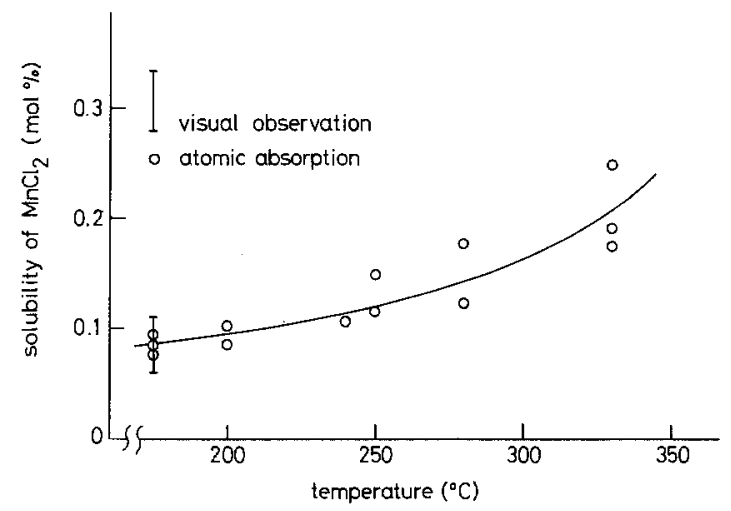

Fig. 1. Solubility of $\mathrm{MnCl}_{2}$ in $\mathrm{NaAlCl}_{4}$ also saturated with $\mathrm{NaCl}$

where $t$ is the temperature in ${ }^{\circ} \mathrm{C}$. At $175^{\circ} \mathrm{C}$ the solubility is found to be $0.086 \pm 0.006 \mathrm{~m} / \mathrm{o} \mathrm{MnCl}_{2}$. In addition, the solubility of $\mathrm{MnCl}_{2}$ increases with the addition of sulfide and with increasing acidity of the melt, i.e., with increasing $\mathrm{AlCl}_{3}$ concentration (not shown in Fig. 1).

Effects of $\mathrm{MnCl}_{2}$ on cathodic overpotentials.-A set of steady-state cathodic polarization curves obtained from $\mathrm{NaCl}$-saturated $\mathrm{NaAlCl}_{4}$ are shown in Fig. 2. In melts both with and without added $\mathrm{MnCl}_{2}$, overpotentials for aluminum deposition on a glassy carbon electrode are significantly larger than that on an aluminum substrate, showing that aluminum is more easily deposited on its own base than on a foreign substrate. The presence of $\mathrm{MnCl}_{2}$ in the melt results in an increase in the deposition overpotential. Stafford (13) and Hayashi (12) reported a similar increase of deposition overpotential of aluminum upon addition of $\mathrm{MnCl}_{2}$ to the melt.

This phenomenon can be explained by a codeposition of manganese and aluminum. In measurements of the deposition potentials of some metals in molten $\mathrm{NaCl}-\mathrm{KCl}-\mathrm{AlCl}_{3}$ at $156^{\circ} \mathrm{C}$, Wade et al. (20) found, with a platinum reference and a platinum cathode, that the deposition potential for aluminum was $-2.02 \mathrm{~V}$ and for manganese $-1.91 \mathrm{~V}$, respec tively. Later they found, with an aluminum reference and a platinum cathode in the same melt, that the deposition potentials for aluminum and manganese were -0.02 and $-0.06 \mathrm{~V}$, respectively (21). Such a small difference in deposition potentials clearly presents the possibility of codeposition of manganese and aluminum from the melt.

Analysis of the electrodeposits from $\mathrm{NaAlCl}_{4}$ saturated with $\mathrm{MnCl}_{2}$ reveals that the content of manganese in the alloy is high, especially when the mole ratio of $\mathrm{Mn} / \mathrm{Al}$ in the melts is taken into account (approximately 1:10 in deposits compared with 1:500 in melts). The results are tabulated in Table I as a function of current density of deposition. The content of $\mathrm{Mn}$ in the deposits varied between 8 and 11 atom percent $(\mathrm{a} / \mathrm{o})$ when the current density varied from 0.29 to $2.86 \mathrm{~mA} / \mathrm{cm}^{2}$, which means that the manganese con-

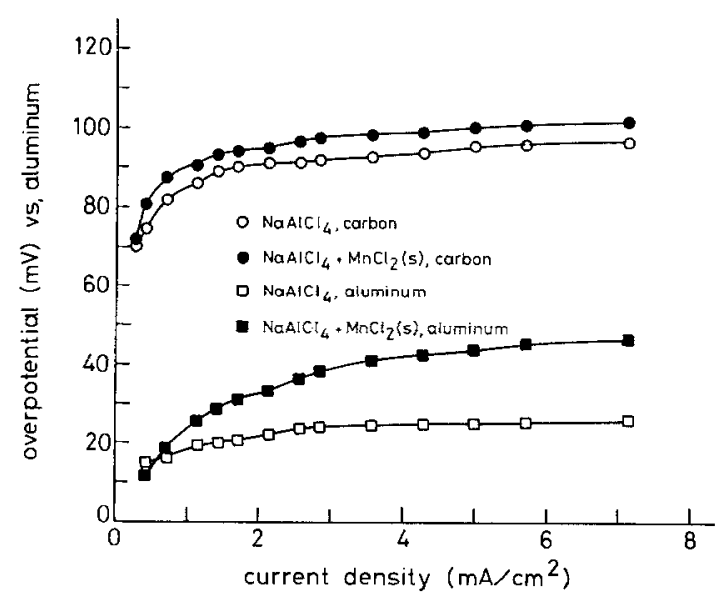

Fig. 2. Cathodic polorization curves at $175^{\circ} \mathrm{C}$ on carbon and aluminum 
Table I. Manganese content in electrodeposits from $\mathrm{NaAlCl}_{4}$ saturated with $\mathrm{NaCl}$ and $\mathrm{MnCl}_{2}$ at $175^{\circ} \mathrm{C}$.

\begin{tabular}{cr}
\hline $\begin{array}{c}\text { Current density } \\
\left(\mathrm{mA} / \mathrm{cm}^{2}\right)\end{array}$ & $\begin{array}{c}\text { Mn content } \\
(\mathrm{a} / \mathrm{o} \mathrm{Mn})\end{array}$ \\
\hline 0.29 & $9.1 \pm 0.5$ \\
0.43 & $7.8 \pm 0.5$ \\
1.43 & $10.5 \pm 1.5$ \\
2.86 & $8.3 \pm 1.0$
\end{tabular}

tent in the deposits is not very dependent on the current density.

Smith et al. (11) reported that binary aluminummanganese alloy deposits containing up to 28 a/o Mn could be obtained from chloroaluminate melts containing small amounts of $\mathrm{MnCl}_{2}$. The manganese content of the electrodeposits was found to increase with increasing $\mathbf{M n C l}_{2}$ and decreasing $\mathrm{AlCl}_{3}$ concentration in the melts. Hayashi (12) found a similar increase in the manganese concentration of manganese-aluminum codeposits as well as an increase in the cathodic polarization when increasing the $\mathrm{MnCl}_{2}$ concentration in the melt. The structures of the electrodeposited aluminum-manganese alloys have been investigated (22), and it was shown that the lowmanganese alloys consisted entirely of a supersaturated solid solution of manganese in aluminum, whereas the high-manganese alloys were comprised of two phases, a supersaturated solid solution and the intermetallic compound, $\mathrm{MnAl}_{6}$, well known from the aluminum-manganese phase diagram (23). The results by Stafford (13) showed that the manganese content of the electrodeposited binary alloys was dependent upon deposition potential as well as the relative concentrations of $\mathrm{Al}_{2} \mathrm{Cl}_{7}^{-}$and $\mathrm{Mn}^{2+}$ ions in the melt.

Morphology of deposits.-Figure 3 shows the observed different morphologies that aluminum can have when it is deposited from $\mathrm{NaAlCl}_{4}$ saturated with $\mathrm{NaCl}$ (first column, a-d), with added $\mathrm{MnCl}_{2}$ (second column, e-h) at different

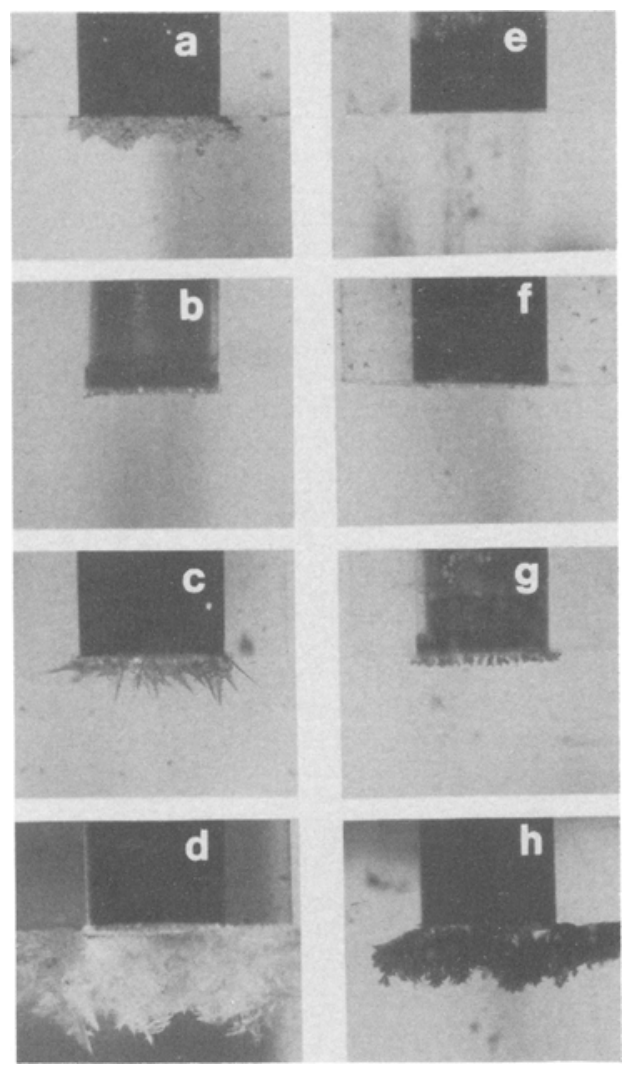

Fig. 3. Morphologies of electrodeposits achieved at current densities of $0.29(\mathrm{a}, \mathrm{e}), 5.0(\mathrm{~b}, \mathrm{f}), 21.4(\mathrm{c}, \mathrm{g})$, and $42.9 \mathrm{~mA} / \mathrm{cm}^{2}(\mathrm{~d}, \mathrm{~h})$ at $175^{\circ} \mathrm{C}$ (a-d) in $\mathrm{NaAlCl}_{4}$ (saturated with $\mathrm{NaCl}$ ) (e-h) in $\mathrm{NaAlCl}_{4}$ (saturated with $\mathrm{NaCl})+\mathrm{MnCl}_{2}(\mathrm{~s})$.

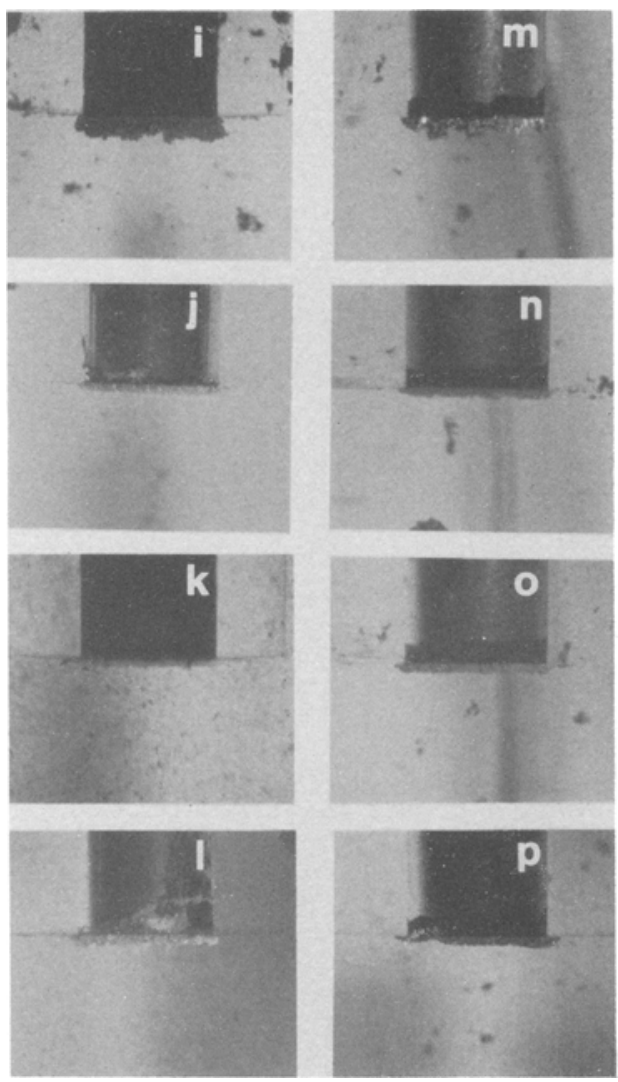

Fig. 4. Morphologies of electrodeposits achieved at current densities of $0.29(\mathrm{i}, \mathrm{m}), 5.0(\mathrm{j}, \mathrm{n}), 21.4(\mathrm{k}, \mathrm{o})$, and $42.9 \mathrm{~mA} / \mathrm{cm}^{2}(1, \mathrm{p})$ at $175^{\circ} \mathrm{C} ;(\mathrm{i}-1)$ in $\mathrm{NaAlCl}_{4}+1.5 \mathrm{~m} / \mathrm{o} \mathrm{NaAlSCl}$, (m-p) in $\mathrm{NaAlCl}_{4}+1.5 \mathrm{~m} / \mathrm{o} \mathrm{NaAlSCl}{ }_{2}+$ $\mathrm{MnCl}_{2}(\sim 0.1 \mathrm{~m} / \mathrm{o})$.

current densities. Similarly, Fig. 4 shows the observed different morphologies that aluminum can have when it is deposited from $\mathrm{NaAlCl}_{4}$ containing sulfide (first column, i-1) and containing both sulfide and $\mathrm{MnCl}_{2}$ (second column, $m-p)$ at different current densities.

It was found previously (1), at lower current densities (below $0.7 \mathrm{~mA} / \mathrm{cm}^{2}$ ), that many precursors for aluminum dendrites were formed initially and spongy deposits were obtained finally due to difficulties in the electronucleation process of deposition (Fig. 3a). In the intermediate range of current densities $\left(1.0<i<10 \mathrm{~mA} / \mathrm{cm}^{2}\right)$, a smooth layer of aluminum deposits was achieved having ca. 5 times larger volume than the theoretical value (Fig. 3b). At higher current densities $\left(>15 \mathrm{~mA} / \mathrm{cm}^{2}\right)$ dendritic or porous deposits often appeared (Fig. $3 \mathrm{c}$ and d).

With addition of a small amount of manganese chloride, the precursors and finally the spongy deposits could be completely avoided, and perfectly dense deposits were obtained at lower current densities (Fig. 3e). Smooth layers of deposits were obtained at current densities up to $20 \mathrm{~mA} / \mathrm{cm}^{2}$ (Fig. 3f); however, at current densities above ca. $25 \mathrm{~mA} / \mathrm{cm}^{2}$, dendritic or porous deposits were formed (Fig. $3 \mathrm{~g}$ and $\mathrm{h}$ ). These dendritic deposits seemed to be different in appearance from those obtained from pure $\mathrm{NaAlCl}_{4}$. As previously demonstrated (1), spongy deposits of aluminum formed at lower current densities can be attributed to the slow rate of electronucleation involved in the deposition process. When $\mathrm{MnCl}_{2}$ additions are present, codeposition of $\mathrm{Al}$ and $\mathrm{Mn}$ apparently promotes the nucleation, and therefore the formation of such spongy deposits is avoided.

In the melt containing $1.5 \mathrm{~m} / \mathrm{o} \mathrm{NaAlSCl} \mathrm{N}_{2}$, aluminum deposits were even more spongy at lower current densities $\left(0.285 \mathrm{~mA} / \mathrm{cm}^{2}\right.$, Fig. $\left.4 \mathrm{i}\right)$. This suggests that the nucleation process of aluminum deposition is more difficult in this case than in pure $\mathrm{NaAlCl}_{4}$ melts. An interesting finding is that smooth aluminum deposits, though very. porous in most cases, were formed at higher current densities (Fig. $4 j$ and $\mathrm{k}$ ), at which dendritic deposits would be formed from 
$\mathrm{NaAlCl}_{4}$ independent of any $\mathrm{MnCl}_{2}$ addition. No dendrites were formed at current densities as high as $42.9 \mathrm{~mA} / \mathrm{cm}^{2}$ (Fig. 4l).

The combination of $\mathrm{MnCl}_{2}$ and sulfide as additives to $\mathrm{NaAlCl}_{4}$ melts resulted in a slight improvement in the spongy deposits at lower current densities (Fig. $4 \mathrm{~m}$ ) compared with those from $\mathrm{NaAlCl}_{4}$ with (Fig. 4i) or without (Fig. 3a) sulfide. However, the deposits were far from as smooth and condensed as the deposits from $\mathrm{NaAlCl}_{4}$ containing only $\mathrm{MnCl}_{2}$ (Fig. 3e). Hence, the presence of sulfide in the melt destroys the effect of manganese chloride. At higher current densities no dendritic deposits were formed (Fig. 4o and p).

Figure 5 shows specific average volumes of electrodeposits obtained from the $\mathrm{NaCl}$-saturated $\mathrm{NaAlCl}_{4}$ without any additives compared with melts containing manganese chloride, sulfide, and both manganese chloride and sulfide additives. Each point is the average value of at least two measurements. At low current densities, the high values of specific volumes of deposits from the $\mathrm{NaAlCl}_{4}$ melts and melts containing sulfide indicate the formation of spongy deposits. The volumes of deposits from melts saturated with $\mathrm{MnCl}_{2}$ were close to the theoretical value, indicating formation of perfectly compact deposits of aluminummanganese alloys.

At intermediate current densities, the volumes of deposits from $\mathrm{NaAlCl}_{4}$ melts and melts containing sulfide and sulfide-manganese chloride in combination were approximately equal and were about five times larger than the theoretical value. Deposits from the melts containing only manganese chloride were significantly more compact, especially at lower current densities.

Current reversal chronopotentiometry.-Current reversal chronopotentiometry was used to investigate the reversibility of aluminum deposited in $\mathrm{NaAlCl}_{4}$ melts with addition of $\mathrm{MnCl}_{2}$, sulfide, and their combination. $1 \mathrm{C} / \mathrm{cm}^{2}$ was applied in each deposition. In order to study the effects of the deposition current on the reversibility of aluminum deposition, an arbitrary constant current of $0.714 \mathrm{~mA} / \mathrm{cm}^{2}$ was used to reoxidize the aluminum deposited at different current densities. A set of chronopotentiograms at a current density of $0.714 \mathrm{~mA} / \mathrm{cm}^{2}$ for both deposition and reoxidation is shown in Fig. 6.

As can be seen from Fig. 6, overpotentials of reoxidation are much higher for the aluminum-manganese alloy than for pure aluminum. When aluminum or aluminummanganese alloy was being reoxidized upon reversal current, the electrode potential was almost constant or increased slightly. When this process was complete, the potential rose rapidly to that of chlorine evolution (at ca. $2.3 \mathrm{~V}$ $v s$. aluminum reference). The transition time was determined from the potential-time curves by extrapolation of the maximum slope at the completion of reoxidization. The coulombic efficiency (charge ratio of reoxidization to deposition) was thus calculated, as shown in Fig. 7.

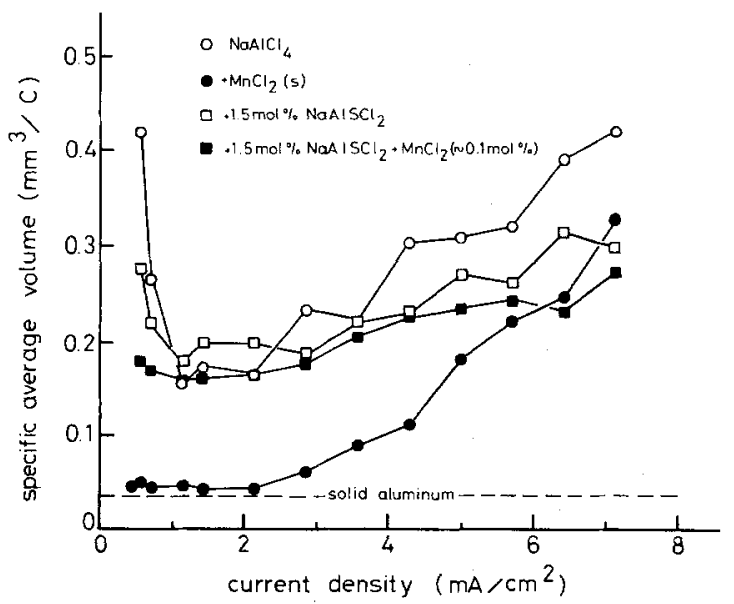

Fig. 5. Specific average volume of deposits, in $\mathrm{mm}^{3} / \mathrm{C}$, on a glassy carbon electrode as a function of current density.

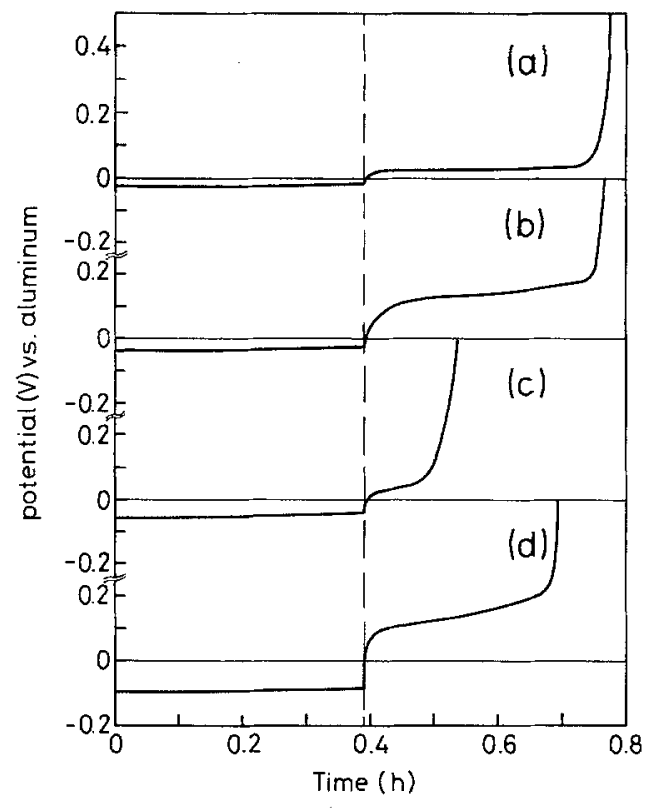

Fig. 6. Current reversal chronopotentiograms on a glassy carbon electrode at $0.714 \mathrm{~mA} / \mathrm{cm}^{2}$ for both deposition and oxidation. Vertical dosh line indicates the reversing of current. (a) in $\mathrm{NaAlCl}_{4}$, (b) in $\mathrm{NaAlCl}_{4}+\mathrm{MnCl}_{2}$ (s), (c) in $\mathrm{NaAlCl}_{4}+1.5 \mathrm{~m} / \mathrm{o} \mathrm{NaAlSCl}$, and (d) in $\mathrm{NaAlCl}_{4}+1.5 \mathrm{~m} / 0 \mathrm{NaAlSCl}_{2}+\mathrm{MnCl}_{2}(\sim 0.1 \mathrm{~m} / \mathrm{o})$.

All values of coulombic efficiencies were less than unity. This has earlier, in both $\mathrm{NaCl}-\mathrm{AlCl}_{3}(24)$ and organic aluminum chloride (25-27), been attributed to the corrosion of aluminum by impurities. In the present study, it was found that this phenomenon was mainly dependent on the interfacial properties between deposits and the electrode, i.e., the adhesion of deposits to the substrate. Through a microscope, it was observed that some forms of small aluminum pieces fell off into the melt during reoxidization, and small aluminum particles remained on the electrode surface during chlorine gas evolution, apparently not adhering well to the electrode.

It can be seen from Fig. 7 that coulombic efficiencies of more than $95 \%$ were obtained at low deposition current densities in $\mathrm{NaAlCl}_{4}$ melts both with and without $\mathrm{MnCl}_{2}$. The coulombic efficiency decreased with increasing deposition current density, more significantly in the melt containing manganese dichloride than in the pure $\mathrm{NaAlCl}_{4}$ melt. Addition of sulfide resulted in much lower coulombic efficiencies (with a maximum at a current density of ca. $0.7 \mathrm{~mA} / \mathrm{cm}^{2}$ ). The addition of $\mathrm{MnCl}_{2}$ to the melts al ready containing sulfide considerably improved the cou-

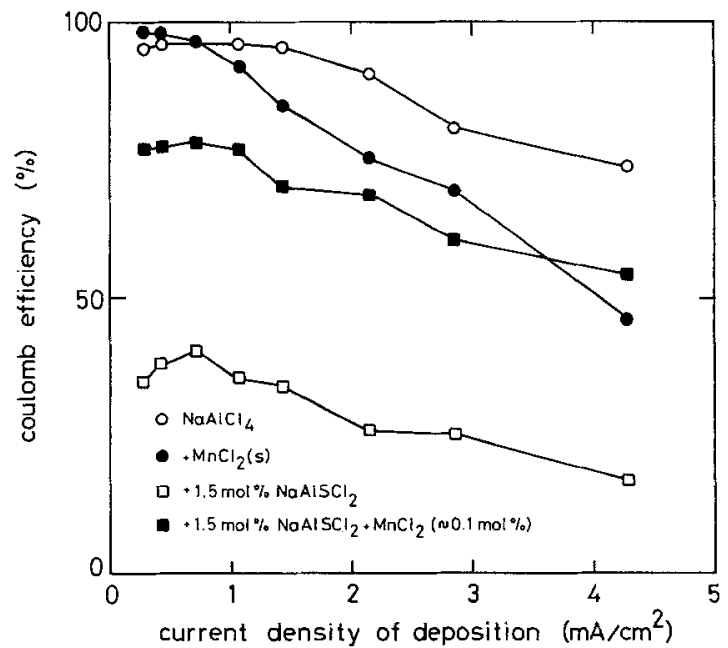

Fig. 7. Coulombic efficiency as a function of current density of deposition. Current density of reoxidation: $0.714 \mathrm{~mA} / \mathrm{cm}^{2}$. Temperature: $175^{\circ} \mathrm{C}$. 
lombic efficiencies, although not as much as without sulfide. An investigation on the mechanism, using several different substrates such as copper, tungsten, nickel, etc., is underway (28).

\section{Conclusions}

The solubility of manganese dichloride was found to be $0.086 \pm 0.006 \mathrm{~m} / \mathrm{o}$ in $\mathrm{NaAlCl}_{4}$ saturated with $\mathrm{NaCl}$ at $175^{\circ} \mathrm{C}$ The addition of such a small quantity of $\mathrm{MnCl}_{2}$ to $\mathrm{NaAICl}_{4}$ melts saturated with $\mathrm{NaCl}$ leads, upon electrolysis, to a codeposition of aluminum-manganese binary alloys, resulting in a formation of smooth, compact deposits at low current densities, below $6 \mathrm{~mA} / \mathrm{cm}^{2}$. Dendritic deposits of the alloy were formed at high current densities, above $25 \mathrm{~mA} / \mathrm{cm}^{2}$.

The presence of sulfide in $\mathrm{NaAlCl}_{4}$ melts tends to cause spongy deposits, and therefore, when both additives are present, destroys the beneficial effects of $\mathrm{MnCl}_{2}$ at lower current densities. At high current densities, however, it prevents dendrite formation.

Cathodic overpotentials of the codeposition of Al-Mn alloys are slightly higher than that of pure aluminum deposition, and overpotentials are ca. $60 \mathrm{mV}$ higher at a glassy carbon electrode than at an aluminum electrode in melts both with and without $\mathrm{MnCl}_{2}$.

Coulombic efficiencies by CRC measurements are high at lower current densities but decrease with increasing current density of deposition. In the melts containing sulfide, coulombic efficiencies are extremely low. In all cases, coulombic efficiencies were found to be less than unity, mainly due to the bad adhesion of the deposits to the substrate. Further investigations are planned by using different substrates.

\section{Acknowledgments}

We gratefully acknowledge the Danish Ministry of Energy, the Danish Technical Research Council, and Myhrwolds Fond for financial support. Peter Jansen is thanked for his programming. Our thanks are also extended to the Institute of Metallurgy, The Technical University of Denmark, for EDX analysis.

Manuscript submitted Oct. 23, 1989; revised manuscript received March 26, 1990.

\section{REFERENCES}

1. Li Qingfeng, H. A. Hjuler, R.W. Berg, and N. J. Bjerrum, This Journal, 13\%, 593 (1990), and references cited herein.
2. P. Fellner, M. Chrenková-Paučírová, A. Silný, and K. Matiašovský, Electrochim. Acta, 25, 189 (1980).

3. K. Grjotheim and $K$. Mathiašovský, Acta Chem, Scand., A34, 666 (1980).

4. P. Fellner, M. Chrenková-Paučírová, and K. Matiašovský, Surf. Technol., 14, 101 (1981).

5. Y. K. Delimarsky and N. K. Tumanova, Electrochim. Acta, 24, 19 (1979).

6. J. Jorne, Y-J. Lii, and K. E. Yee, This Journal, 134, 1399 (1987).

7. R. Midorikawa, Denki Kagaku, 24, 336 (1956).

8. R. Midorikawa, ibid., 24, 562 (1956).

9. K. Nisancioglu, L. Odden, and A. P. Grande, Abstract 551, p. 783, The Electrochemical Society Extended Abstracts, Vol. 87-1, Philadelphia, PA, May 10-15, 1987.

10. N. Koura, This Journal, 127, 1529 (1980).

11. L. W. Austin, M. G. Vucich, and E. J. Smith, Electrochem. Technol., 1, 267 (1963).

12. T. Hayashi, Proceedings of the 1st International Symposium on Molten Salt Chemical Technology, p. 53, Kyoto, Japan (1983).

13. G. R. Stafford, This Journal, 136, 635 (1989).

14. M. Paučírová and K. Matiašovský, Electrodep. Surf. Treat., 3, 121 (1975)

15. R. Midorikawa, Denki Kagaku, 24, 419 (1956).

16. Unpublished work.

17. H. A. Hjuler, R. W. Berg, and N. J. Bjerrum, Power Sources, 10, 1 (1985).

18. R. W. Berg, H. A. Hjuler, and N. J. Bjerrum, Inorg. Chem., 23, 557 (1984).

19. R. W. Berg, S. von Winbush, and N. J. Bjerrum, ibid., 19, $2688(1980)$.

20. W. H. Wade, G. O. Twellmeyer, and L. F. Yntema, Trans. Electrochem., 78, 77 (1940).

21. R. G. Verdieck and L. F. Yntema, J. Phys. Chem., 46, 344 (1942).

22. H. J. Read and D. A. Shores, Electrochem. Technol., 4, 526 (1966).

23. R. P. Elliott, "Constitutions of Binary Alloy," 1st Supplement, McGraw Hill, New York (1965).

24. R. J. Gale and R. A. Osteryoung, This Journal, 121, 983 (1974).

25. J. Robinson and R.A. Osteryoung, ibid., 127, 122 (1980).

26. Qi-Xian Qin and M. Skyllas-Kazacos, J. Electroanal. Chem. 168, 193 (1984).

27. P. K. Lai and M. Skyllas-Kazacos, Electrochim. Acta, 32, 1443 (1987).

28. Li Qingfeng, H. A. Hjuler, R. W. Berg, and N. J. Bjerrum, Submitted to This Journal.

\title{
A Three-Phase Fluidized Bed Fuel Cell
}

\author{
H. Tanaka, N. Enoki, N. Kaneki, H. Sakai, K. Shimada, and H. Hara \\ Department of Chemical Engineering, Muroran Institute of Technology, Muroran 050, Japan
}

\begin{abstract}
Flat porous electrodes are presently used in fuel cells, but they require careful porosity control, resulting in a complex production process. The development of a new type of electrode with a simpler structure as well as a larger effective area would be desirable.

This study proposes a three-phase fluidized bed electrode that can be used in simple electrode alkaline fuel cells. There are several publications on fluidized bed elec-
\end{abstract}

trodes that combine two liquid phases or a solid and a liquid phase $(1,2)$. However, we have not found any publication on three-phase fluidized bed electrodes that combine solids, liquids, and gases. The electrode structure consists of a glass tube containing an electrolytic solution and catalytic particles. Hydrogen or oxygen gas is introduced into the tube from the bottom, while the solution and catalyst are agitated in the fluidized bed. Under these conditions, 